\title{
ANALISIS FAKTOR-FAKTOR YANG MEMPENGARUHI SURPLUS UNDERWRITING ASURANSI UMUM SYARIAH DI INDONESIA 1 )
}

\author{
Febrinda Eka Damayanti \\ Program Studi S1 Ekonomi Islam-Fakultas Ekonomi dan Bisnis-Universitas Airlangga \\ Email: febrinda.eka-12@feb.unair.ac.id \\ Imron Mawardi \\ Departemen Ekonomi Syariah-Fakultas Ekonomi dan Bisnis-Universitas Airlangga \\ Email: imron-m@feb.unair.ac.id
}

\begin{abstract}
:
The purpose of this research is to know whether factors of Surplus Underwriting (participant contributions, claims and investment returns) have significant effect, both simultaneously and partially. The method used in this research is quantitative method and also using the secondary data which obtained from financial reports and other reports started from 2012 2014. The population is sharia general insurance and sharia unit of general insurance in Indonesia. The sample are 13 general insurance companies that comply with the spesified sample criteria. Analysis technique used is multiple linier regression analysis of panel data.
\end{abstract}

Keywords: participant contributions, claims, investment returns and surplus underwriting.

\section{PENDAHULUAN}

\section{Latar Belakang}

Sebagai negara yang mayoritas penduduknya beragama Islam, keberadaan lembaga kevangan yang sesuai dengan prinsip syariah sangat dibutuhkan. Salah satunya adalah asuransi syariah. Keberadaan asuransi syariah mampu menarik minat masyarakat muslim karena dapat menjangkau kebutuhan masyarakat akan perlindungan terhadap risiko tertentu dengan pengelolaan sesuai dengan syariat Islam.

Awal berdirinya asuransi syariah di Indonesia dimulai pada tahun 1994 yang ditandai dengan berdirinya salah satu perusahan asuransi syariah, yaitu Asuransi Syariah Takaful yang prakarsai oleh Ikatan Cendekiawan Muslim Indonesia (ICMI) melalui Yayasan Abdi Bangsa, Bank Muamalat Indonesia, PT Asuransi Jiwa serta beberapa pengusaha Muslim Indonesia. Asuransi syariah mulai beroperasi secara resmi ijin operasional asuransi yang diperoleh dari Departemen Keuangan melalui Surat Keputusan Nomor: Kep-385/KMK.017/1994. Pendirian asuransi syariah merupakan implementasi dari nilai-nilai Syariah yang termuat di dalam Al-Qur'an dan Al-Sunnah, serta pendapat ulama atau fuqaha yang tertuang dalam karya-karyanya.

Berdasarkan data dari Otoritas Jasa Keuangan (OJK) tahun 2014, saat ini sudah terdapat 49 perusahaan asuransi syariah yang terdiri dari 21 asuransi jiwa syariah, 25 asuransi umum syariah, dan 3 reasuransi syariah.

Asuransi syariah di Indonesia lebih dikenal dengan istilah takaful yang berarti saling menanggung atau menanggung Tugu Mandiri, Departemen Keuangan Rl, bersama. Takaful dalam pengertian 1) Jurnal ini merupakan bagian dari Skripsi yang ditulis oleh Febrinda Eka Damayanti; 041211432099 , yang diuji pada tanggal 1 Juni 2016 
Febrinda Eka Damayanti, et al/Jurnal Ekonomi Syariah Teori dan Terapan Vol. 3 No. 12 Desember 2016: 989-1005; ANALISIS FAKTOR-FAKTOR YANG MEMPENGARUHI SURPLUS UNDERWRITING ASURANSI UMUM SYARIAH DI INDONESIA

muamalah mengandung arti saling menganggung resiko di antara sesama manusia sehingga diantara satu dengan lainnya menjadi penanggung atas risiko masing-masing (Dewi, 2004:136). Sedangkan pengertian asuransi syariah menurut Fatwa Dewas Syariah Nasional (DSN) No. 21/DSN-MUI/3/2012 tentang Asuransi Syariah adalah

"usaha saling melindungi dan tolong menolong di antara sejumlah orang/pihak melalui investasi dalam bentuk aset dan atau tabbaru' yang memberikan pola pengembalian untuk menghadapi risiko tertentu melalui akad (perikatan) yang sesuai syariah."

Berdasarkan jenis risiko yang ditanggungnya, asuransi syariah dibedakan menjadi dua yaitu takaful kelvarga (asuransi jiwa) dan takaful umum (asuransi kerugian) (Rahman, 2011). Takaful keluarga merupakan bentuk takaful yang memberikan perlindungan dalam menghadapi kematian dan kecelakaan atas diri peserta takaful. Sedangkan takaful umum adalah bentuk takaful yang memberi perlindungan dalam menghadapi bencana atau kecelakaan atas harta milik peserta takaful.

Takaful kerugian memiliki konsep tolong menolong atau saling melindungi dalam kebenaran. Bentuk tolong menolong ini diwujudkan dalam dana kebajikan (dana tabarru') sebesar yang ditetapkan (Sula, 2004:225). Dana tabarru' adalah dana hibah yang dikumpulkan oleh peserta sebagai dana tolong menolong (dana kebajikan) untuk membantu peserta yang sedang mendapatkan musibah. Dana tabarru' tersebut berasal dari kontribusi peserta asuransi. Menurut Billah (1999) dalam Sula (2004:246) kontribusi (al musahamah) dalam perjanjian takaful adalah pertimbangan keuangan (al-'iwad) dari bagian peserta yang merupakan kewajiban yang muncul dari perjanjian antara peserta dan pengelola. Kontribusi yang telah dibayarkan oleh peserta asuransi akan menjadi tanggung jawab bagi perusahaan asuransi untuk mengelolanya dengan baik.

Untuk mengelola dana tabarru' peserta, perusahanaan asuransi syariah melaksanakan kegiatan investasi sesuai dengan syariat islam. Perusahaan asuransi syariah hanya boleh menginvestasikan dananya kepada lembaga keuangan islam seperti bank syariah, BPRS, obligasi syariah, dan kegiatan lainnya yang sesuai dengan prinsip-prinsip syariah. Perusahaan asuransi syariah akan memperoleh keuntungan dari hasil investasi. Hasil investasi tersebut kemudian dimasukkan dalam rekening dana tabarru'.

Dalam proses operasionalnya, perusahaan asuransi syariah tidak terlepas dari penerapan fungsi manajemen underwriting. Underwriting merupakan proses menyeleksi risiko dan mengklasifikasikannya sesuai dengan tingkat yang dapat ditanggung oleh perusahaan. Dalam hal ini, risiko yang muncul adalah klaim yang mungkin akan dihadapi oleh perusahaan asuransi di masa yang akan datang. Klaim 
Febrinda Eka Damayanti, et al/Jurnal Ekonomi Syariah Teori dan Terapan Vol. 3 No. 12 Desember 2016: 989-1005; ANALISIS FAKTOR-FAKTOR YANG MEMPENGARUHI SURPLUS UNDERWRITING ASURANSI UMUM SYARIAH DI INDONESIA

merupakan proses pengajuan oleh peserta asuransi untuk mendapatkan vang pertanggungan setelah peserta melaksanakan seluruh kewajibannya kepada perusahaan asuransi berupa penyelesaian pembayaran premi sesuai dengan kesepakatan sebelumnya (Huda dan Mustafa, 2009:349). Pengajuan klaim terjadi ketika peserta asuransi mendapat musibah seperti meninggal dunia, kebakaran, gempa bumi, dan musibahmusibah lain yang datangnya tidak terduga. Proses pengajuan klaim dilaksanakan sesuai dengan kesepakatan awal pada akad.

Ketika peserta asuransi ingin mengajukan klaim, perusahaan asuransi sebagai pengelola asuransi wajib menyelesaikan proses klaim secara cepat, tepat, dan efisien sesuai dengan amanah yang diterimanya, sebagaimana firman Allah SWT. dalam QS. Al-An-Faal(8) ayat 27

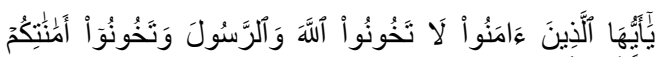

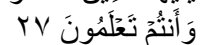
Yaa ai-yuhaal-ladziina aamanuu laa takhuunuullaha warrasuula watakhuunue amaanaatikum waantum ta'lamuun(a)

Artinya : "Hai orang-orang beriman, janganlah kamu, menghianati Allah dan Rasul (Muhammad), dan juga janganlah kamu menghianati, amanat-amanat yang dipercayakan kepadamu, sedang kamu mengetahui." (Departemen Agama RI, 2005: 350)

Ayat ini menerangkan bahwa amanat-amanat yang dipercayakan jangan dikhianati, karena amanah tersebut merupakan perbuatan wajib. Oleh karena itu, setiap amanah wajib di laksanakan dengan sebaik-baiknya (ArRivai, 2000:51 1 dalam huda 2009:349)

Perbedaan klaim pada asuransi syariah dan asuransi konvensional terletak pada proses pembayarannya. Pada asuransi konvensional, pembayaran klaim diambil dari rekening dana perusahaan. Sedangkan pada asuransi syariah, sumber dari pembayaran klaim diambil dari rekening dana tabarru' (dana kebajikan) yang telah diniatkan oleh semua peserta asuransi syariah untuk kepentingan tolong menolong.

Jika pada akhir periode jumlah kontribusi peserta lebih besar dari klaim dan beban lainnya, akan terjadi surplus underwriting pada dana tabarru'. Dalam Peraturan Otoritas Jasa Keuangan, surplus underwriting adalah selisih lebih total kontribusi Peserta ke dalam Dana Tabarru' ditambah kenaikan Aset reasuransi setelah dikurangi pembayaran santunan/klaim, kontribusi reasuransi dan kenaikan cadangan teknis, dalam satu periode tertentu. Ketika terjadi surplus, dana dapat disimpan sebagian sebagai dana cadangan tabarru' dan dapat dibagikan sebagian lainnya kepada perusahaan asuransi dan para peserta sepanjang disepakati oleh para peserta.

Penelitian ini menggunakan tiga variabel independen yaitu kontribusi peserta, klaim dan hasil investasi. Ketiga variabel ini akan diteliti untuk mengetahui diantara variabel tersebut mana yang memiliki pengaruh paling besar terhadap variabel dependennya. Sedangkan 
Febrinda Eka Damayanti, et al/Jurnal Ekonomi Syariah Teori dan Terapan Vol. 3 No. 12 Desember 2016: 989-1005; ANALISIS FAKTOR-FAKTOR YANG MEMPENGARUHI SURPLUS UNDERWRITING ASURANSI UMUM SYARIAH DI INDONESIA

variabel dependen yang digunakan adalah surplus underwriting pada asuransi umum syariah dengan periode waktu pada tahun 2012-2014. Penelitian ini menjadi penting sebab ketika asuransi syariah memperoleh surplus underwriting, dana tersebut dapat digunakan sebagai cadangan bagi pembayaran klaim peserta asuransi di masa depan. Sehingga resiko gagal bayar terhadap klaim peserta dapat diminimalisir. Hal tersebut juga dapat meningkatkan kepercayaan masyarakat terhadap jasa dan layanan perusahaan asuransi syariah. Atas dasar pemikiran tersebut penulis akan mengadakan penelitian yang berjudul "Pengaruh Kontribusi Peserta, Klaim, dan Hasil Investasi terhadap Surplus Underwriting Asuransi Umum Syariah di Indonesia."Berdasarkan uraian latar belakang di atas, maka peneliti merumuskan masalah penelitian sebagian berikut:

1. Apakah kontribusi peserta, klaim dan hasil investasi secara simultan berpengaruh terhadap surplus underwriting asuransi umuum syariah di Indonesia??

2. Apakah kontribusi peserta, klaim dan hasil investasi secara parsial berpengaruh terhadap surplus underwriting asuransi umum syariah di Indonesia?

Adapun tujuan penelitian ini adalah:

1. Untuk mengetahui pengaruh kontribusi peserta, klaim dan hasil investasi secara simultan terhadap surplus underwriting asuransi Syariah di Indonesia.

2. Untuk mengetahui pengaruh kontribusi peserta, klaim dan hasil investasi secara parsial terhadap surplus underwriting asuransi Syariah di Indonesia.

\section{LANDASAN TEORI}

Dalam Kitab Undang-Undang (UU) Hukum Dagang pasal 246, pengertian asuransi atau pertanggungan adalah

suatu perjanjian, dengan nama seorang penanggung mengikat diri kepada seorang tertanggung, dengan menerima premi, untuk memberikan penggantian karena suatu kerugian, kerusakan atau kehilangan keuntungan yang diharapkan, yang mungkin akan dideritanya karena suatu peristiwa tertentu (Sudarsono, 2003:1 12).

Asuransi dalam pengertian muamalah adalah saling menanggung risiko di antara sesama manusia sehingga diantara satu dengan lainnya menjadi penanggung atas risiko masing-masing. Dengan demikian, gagasan mengenai asuransi takaful berkaitan dengan unsur saling menanggung resiko di antara para peserta asuransi, dimana peserta yang satu menjadi penanggung peserta yang lainnya. Perusahaan asuransi takaful hanya bertindak sebagai fasilitator saling menganggung di antara para peserta asuransi (Dewi, 2004:122).

Di dalam asuransi takaful yang sebenarnya terjadi adalah saling bertanggung jawab, bantu membantu dan melindungi para peserta sendiri. Berdasarkan jenis risiko yang ditanggungnya, asuransi syariah 
Febrinda Eka Damayanti, et al/Jurnal Ekonomi Syariah Teori dan Terapan Vol. 3 No. 12 Desember 2016: 989-1005; ANALISIS FAKTOR-FAKTOR YANG MEMPENGARUHI SURPLUS UNDERWRITING ASURANSI UMUM SYARIAH DI INDONESIA

dibedakan menjadi dua yaitu takaful keluarga (asuransi jiwa) dan takaful umum (asuransi kerugian)(Rahman, 2011).

1. Takaful umum (asuransi jiwa) merupakan bentuk takaful yang memberikan perlindungan dalam menghadapi kematian dan kecelakaan atas diri peserta takaful.

2. Takaful umum (asuransi kerugian) adalah bentuk takaful yang memberi perlindungan dalam menghadapi bencana atau kecelakaan atas harta milik peserta takaful.

Takaful umum (kerugian) memiliki konsep tolong menolong atau saling melindungi dalam kebenaran. Bentuk tolong menolong ini diwujudkan dalam kontribusi dana kebajikan (dana tabarru') sebesar yang ditetapkan. Apabila salah satu dari peserta takaful mendapat musibah, maka peserta lainnya ikut menanggung risiko, dimana klaimnya dibayarkan dari akumulasi dana tabarru' yang terkumpul (Sula, 2004:225).

Secara umum, akad yang ada dalam konsep asuransi syariah merupakan akad tijarah dan juga akad tabarru'. Akad tijarrah yang dipakai adalah akad mudharabah, sedang akad tabarru' yang digunakan merupakan hibah. Dalam akad tijarah perusahaan asuransi islam bertindak sebagai mudharib yang mengelola dana dari peserta, sementar peserta bertindak sebagai shahibul maal. Sementara dalam akad tabarru' peserta asuransi syariah memberikan hibah yang digunakan untuk tolong-menolong peserta lain yang terkena musibah, sementara perusahaan bertindak sebagai pengelola dana hibah (Huda, 2010;181).

Menurut Sula (2004:246), kontribusi (al-Musahamah) adalah suatu bentuk kerja sama mutual di mana tiap-tiap peserta memberikan kontribusi dana kepada suatu perusahaan dan peserta tersebut berhak memperoleh kompensasi atas kontribusinya tersebut berdasar besarnya saham (premi) yang ia miliki (bayarkan).

Menurut Billah (1999) dalam Sula (2004) kontribusi (al musahamah) dalam perjanjian takaful adalah pertimbangan keuangan (al-'iwad) dari bagian peserta yang merupakan kewajiban yang muncul dari perjanjian antara peserta dan pengelola. Perjanjian takaful dalam kerja sama mutual yang mana pertimbangan dibutuhkan tidak hanya dari satu pihak, tapi kedua pihak sehingga pengelola juga secara juga secara sama terikat dengan perjanjian tadi serta dalam ganti-rugi dan keuntungan. Kewajiban penyelesaian pertimbangan dalam transaksi kerja sama mutual disahkan oleh Allah.

Klaim merupakan pengajuan hak yang dilakukan oleh tertanggung kepada penanggung untuk mendapatkan haknya berupa pertanggungan atas kerugian berdasarkan perjanjian atau akad yang telah dibuat. Dengan kata lain, klaim asuransi adalah proses pengajuan oleh peserta asuransi untuk mendapatkan vang pertanggungan setelah peserta melakukan seluruh kewajibannya kepada 
Febrinda Eka Damayanti, et al/Jurnal Ekonomi Syariah Teori dan Terapan Vol. 3 No. 12 Desember 2016: 989-1005; ANALISIS FAKTOR-FAKTOR YANG MEMPENGARUHI SURPLUS UNDERWRITING ASURANSI UMUM SYARIAH DI INDONESIA

perusahaan asuransi berupa penyelasaian pembayaran premi sesuai dengan kesepakatan sebelumnya (Huda dan Mustafa, 2009:349).

$$
\text { Investasi kevangan menurut }
$$

syariah dapat diartikan dengan kegiatan perdagangan atau kegiatan usaha, dimana kegiatan usaha dapat berbentuk usaha yang berkaitan dengan suatu produk atau aset maupun usaha jasa. Namun, investasi keuangan menurut syariah harus terkait secara langsung dengan suatu aset atau kegiatan usaha yang spesifik dan menghasilkan manfaat, karena hanya atas manfaat tersebut dapat dilakukan bagi hasil (Sula, 2004:359).

Dalam Peraturan Otoritas Jasa Keuangan, surplus underwriting adalah selisih lebih total kontribusi Peserta ke dalam Dana Tabarru' ditambah kenaikan Aset reasuransi setelah dikurangi pembayaran santunan/klaim, kontribusi reasuransi dan kenaikan cadangan teknis, dalam satu periode tertentu.

$$
\text { Berdasarkan latar belakang, }
$$
rumusan masalah, tujuan penelitian, landasan teori yang telah dikemukakan maka hipotesis dalam penelitian ini adalah:

1. Kontribusi peserta, klaim dan hasil investasi secara simultan berpengaruh signifikan terhadap surplus underwriting asuransi umum syariah di Indonesia

2. Kontribusi peserta, klaim, dan hasil investasi secara parsial berpengaruh signifikan terhadap surplus underwriting asuransi umum syariah di Indonesia

\section{METODE PENELITIAN}

\section{Pendekatan Penelitian}

Pendekatan yang digunakan dalam penelitian ini adalah pendekatan kuantitatif. Alat analisis kuantitatif yang digunakan dalam penelitian ini adalah regresi berganda data panel.

\section{Variabel Dependen}

1. Surplus Underwriting

Variabel surplus underwriting dalam penelitian ini adalah $(\mathrm{Y})$ adalah hasil pengurangan dari permi bersih/netto akhir tahun dikurangi dengan total jumlah klaim yang terjadi. Apabila hasil dari pengurangan tersebut positif, maka perusahaan asuransi akan memperoleh surplus. Sebaliknya, jika pengurangan tersebut hasilnya adalah negatif, maka perusahaan asuransi akan mengalami defisit. Penelitian ini menggunakan data surplus underwriting dana tabarru' pada laporan surplus underwriting dana tabarru' laporan kevangan perusahaan asuransi umum syariah dari tahun 2012-2014

\section{Variabel Independen}

1. Kontribusi peserta

Dalam penelitian ini variabel kontribusi peserta adalah suatu bentuk kerja sama mutual di mana tiap-tiap peserta memberikan kontribusi dana kepada suatu perusahaan dan peserta tersebut berhak memperoleh kompensasi atas 
kontribusinya tersebut berdasar besarnya saham (premi) yang ia miliki (bayarkan). Penelitian ini menggunakan data Kontribusi Bruto pada laporan surplus underwriting dana tabarru' laporan keuangan perusahaan asuransi umum syariah dari tahun 2012-2014

2. Klaim

Variabel klaim adalah hak peserta asuransi yang wajib diberikan oleh perusahaan asuransi sesuai dengan kesepakatan dalam akad. Klaim dapat dilakukan ketika peserta asuransi mengalami musibah. Pembayaran klaim pada asuransi syariah diambil dari dana tabarru'. Penelitian ini menggunakan data pembayaran klaim pada laporan surplus underwriting dana tabarru' laporan keuangan perusahaan asuransi umum syariah dari tahun 2012-2014

3. Hasil Investasi

Variabel Hasil investasi adalah penghasilan dari portofolio hasil investasi pada aktiva perusahaan asuransi syariah. Penelitian ini menggunakan data pendapatan investasi neto pada laporan surplus underwriting dana tabarru' laporan keuangan perusahaan asuransi umum syariah dari tahun 2012-2014

\section{Jenis dan Sumber Data}

Dalam penelitian ini jenis data yang digunakan adalah data sekunder. Data sekunder dalam penelitian ini berupa data panel yaitu data keuangan yang diperoleh dari laporan kevangan perusahaan asuransi umum syariah dari tahun 2012-2014. Data panel adalah data gabungan atara time series dan cross section.

\section{Populasi dan Sampel}

Populasi yang digunakan yaitu Industri asuransi umum syariah di Indonesia sebanyak 26 perusahaan asuransi yang meliputi 3 perusahaan asuransi umum syariah dan 23 unit syariah pada perusahaan asuransi umum.

Sengakan Teknik pengambilan sampel yang digunakan dalam penelitian ini adalah teknik sampling purposive. Pertimbangan yang diambil dalam penentuan sampel pada penelitian ini adalah menggunakan sampel perusahaan asuransi umum syariah dan unit syariah perusahaan asuransi umum di Indonesia yang laporan keuangannya terpublikasi dan sesuai dengan kualifikasi yang dibutuhkan. Data yang digunakan dalam penelitian sebanyak 39 data, dengan sampel sebanyak 13 perusahaan dengan melakukan penelitian pada perusahaan asuransi umum yaitu satu perusahaan asuransi umum syariah dan 12 unit syariah perusahaan asuransi umum dengan periode waktu 2012 sampai dengan 2014.

\section{Teknik Analisis}

\section{Regresi Data Panel}

Menurut Greene (1991:481) dalam mengestimasi data panel terdapat tiga pendekatan yang biasa dilakukan, yaitu 
Febrinda Eka Damayanti, et al/Jurnal Ekonomi Syariah Teori dan Terapan Vol. 3 No. 12 Desember 2016: 989-1005; ANALISIS FAKTOR-FAKTOR YANG MEMPENGARUHI SURPLUS UNDERWRITING ASURANSI UMUM SYARIAH DI INDONESIA

model OLS pooled, model fixed effect (FEM), model random effect (REM).

\section{OLS Pooled atau Common Effect}

Teknik yang paling sederhana untuk mengestimasi data panel adalah hanya dengan mengkombinasikan data time series dan cross section. Dengan hanya menggabungkan data tersebut tanpa melihat perbedaan antar waktu dan individu, maka dapat menggunakan metode OLS untuk mengestimasi model data panel.

\section{Fixed Effect}

Model ini didasarkan adanya perbedaan intersep antara subjek penelitian namun intersepnya sama antar waktu. Selain itu model ini juga mengasumsikan bahwa koefisien regresi (slope) adalah tetap untuk antar subjek penelitian dan antar waktu

\section{Random Effect}

Model ini mengestimasi data panel dimana variabel gangguan mungkin saling berhubungan antar waktu dan antar inidividu dan diasumsikan setiap subjek penelitan memiliki perbedaan intersep.

Untuk menentukan teknik yang paling tepat dalam mengestimasi regresi data panel, terdapat beberapa pengujian yang dilakukan. Pertama adalah uji statistik $F$ (Uji Chow) yang digunakan untuk memilih antara metode CEM atau FEM. Pengambilan keputusan uji chow didasarkan dari nilai probabilitas, dimana jika p-value $<0,05$ maka penggunaan metode FEM lebih baik daripada metode CEM. Yang kedua adalah uji Hausman yang digunakan untuk memilih antara metode FEM atau REM. Pengambilan keputusan juga didasarkan dari nilai probabilitas, dimana jika p-value < 0,05 maka metode FEM lebih baik dari REM.

Metode panel memiliki beberapa keunggulan yang mana keunngulan tersebut dapat meminimalkan bias yang mungkin ditimbulkan oleh agregasi data individu. Keunggulan-keunggulan tersebut memiliki implikasi pada tidak harus dilakukan pengujian asumsi klasik dalam model data panel (Verbeek (2000); Gujarati (2003); Wibisono (2005); Aulia (2004:27) dalam Ajija (2011:52)).

\section{Uji Hipotesis}

Uji $t$

Uji $\dagger$ adalah pengujian terhadap koefisien dari variabel bebas secara parsial. Uji ini dilakukan untuk membuktikan variabel independen secara individu mempengaruhi variabel dependen. Pengujian dilakukan dengan menggunakan significance level 0,05 $(a=5 \%)$. Apabila signifikansi $<0,05$, maka $\mathrm{H}_{0}$ ditolak atau secara parsial variabel independen berpengaruh secara signfikan terhadap variabel dependen. Sebaliknya, bila signifikansi $>0,05$ maka $\mathrm{H}_{0}$ diterima atau secara parsial variabel independen berpengaruh tidak signifikan terhadap variabel dependen.

Uji F

Uji $F$ adalah pengujian model secara keseluruhan. Oleh karena itu, uji $F$ 
Febrinda Eka Damayanti, et al/Jurnal Ekonomi Syariah Teori dan Terapan Vol. 3 No. 12 Desember 2016: 989-1005; ANALISIS FAKTOR-FAKTOR YANG MEMPENGARUHI SURPLUS UNDERWRITING ASURANSI UMUM SYARIAH DI INDONESIA

ini lebih relevan dilakukan pada regresi berganda. Uji $F$ dilakukan untuk mengevaluasi pengarh variabel bebas terhadap variabel terikat secara bersamasama. Pengujian dilakukan dengan menggunakan significance level 0,05 $(a=5 \%)$. Apabila signifikansi $<0,05$, maka $\mathrm{H}_{0}$ ditolak atau secara simultan semua variabel independen berpengaruh secara signifikan terhadap variabel dependen.

\section{Koefisien Determinasi}

Koefisien determinasi

digunakan untuk mengukur persentase total variasi variabel dependen yang

dapat dijelaskan oleh variabel independen dalam garis regresi.

\section{HASIL DAN PEMBAHASAN}

Berdasarkan tabel 1 dapat diketahui bahwa dengan melakukan uji chow, cross-section chi-square sebesar 0,2844 yang berarti lebih dari 0,05. Sehingga metode CEM dipilih dalam penelitian ini.

Tabel 1.

Hasil Perhitungan Uji Chow

\begin{tabular}{|c|c|c|c|}
\hline Effects Test & Statistic & d.f. & Prob. \\
\hline $\begin{array}{c}\text { Cross- } \\
\text { section F }\end{array}$ & 0,846158 & $(12,23)$ & 0.6067 \\
\hline $\begin{array}{c}\text { Cross- } \\
\text { section } \\
\text { Chi-square }\end{array}$ & 14,26097 & 12 & 0.2844 \\
\hline
\end{tabular}

Sumber: Data Diolah, lihat lampiran 2.

Tabel 2.

Output EViews 8 Estimasi Data Panel dengan metode CEM

\begin{tabular}{|c|c|c|c|c|}
\hline \multicolumn{5}{|c|}{$\begin{array}{l}\text { Dependent Variable: Y } \\
\text { Method: Panel Least Squares } \\
\text { Date: } 04 / 29 / 16 \text { Time: } 00: 22 \\
\text { Sample: } 20122014 \\
\text { Periods included: } 3 \\
\text { Cross-sections included: } 13 \\
\text { Total panel (balanced) observations: } 39\end{array}$} \\
\hline Variable & Coefficient & Std. Error & t-Statistic & Prob. \\
\hline $\mathrm{C}$ & $2.25 \mathrm{E}+09$ & $2.21 \mathrm{E}+09$ & 1.015976 & 0.3166 \\
\hline $\mathrm{X} 1$ & 0.155330 & 0.052570 & 2.954714 & 0.0056 \\
\hline $\mathrm{X} 2$ & -0.235807 & 0.099457 & -2.370953 & 0.0234 \\
\hline $\mathrm{X} 3$ & -1.654267 & 1.284985 & -1.287382 & 0.2064 \\
\hline R-squared & 0.217852 & \multicolumn{2}{|c|}{ Mean dependent var } & $4.06 \mathrm{E}+09$ \\
\hline Adjusted R-squared & 0.150810 & \multicolumn{2}{|c|}{ S.D. dependent var } & $9.20 \mathrm{E}+09$ \\
\hline S.E. of regression & $8.48 \mathrm{E}+09$ & \multirow{2}{*}{\multicolumn{2}{|c|}{$\begin{array}{l}\text { Akaike info criterion } \\
\text { Schwarz criterion }\end{array}$}} & 48.65660 \\
\hline Sum squared resid & $2.52 \mathrm{E}+21$ & & & 48.82722 \\
\hline Log likelihood & -944.8037 & \multirow{2}{*}{\multicolumn{2}{|c|}{$\begin{array}{l}\text { Hannan-Quinn criter. } \\
\text { Durbin-Watson stat }\end{array}$}} & 48.71782 \\
\hline F-statistic & 3.249512 & & & 1.808231 \\
\hline Prob(F-statistic) & 0.033273 & \multicolumn{2}{|c|}{ Durbin-Watson stat } & \\
\hline
\end{tabular}

Sumber: Data Diolah, lihat lampiran 2

Uji F

Berdasarkan tabel dapat

diketahui bahwa signifikansi yang

dihasilkan sebesar 0,033273. Nilai

signifikansi tersebut lebih kecil dari 0,05.

Sehingga $\mathrm{Ha}_{1}$ diterima. Cara lain yang dapat digunakan untuk mengetahui pengaruh secara simultan variabel independen terhadap variabel dependen adalah dengan membandingkan antara $F$ hitung dengan $F$ kritis. $F$ tabel dalam penelitian ini adalah 2,92 dan $\mathrm{F}$ hitungnya 
3,249512. F hitung lebih besar dari $F$ kritis sehingga $\mathrm{Hal}_{\mathrm{l}}$ diterima. Sehingga dapat disimpulkan bahwa variabel Kontribusi peserta, Klaim, dan Hasil Investasi secara simultan berpengaruh signifikan terhadap Surplus Underwriting asuransi umum syariah di Indonesia.

Tabel 3.

Output EViews 7 Hasil Uji F

\begin{tabular}{|c|c|}
\hline F-statistic & 3,249512 \\
\hline Prob(F-statistic) & 0,033273 \\
\hline
\end{tabular}

Sumber: Data Diolah, lihat lampiran 2.

Uji $t$

Berdasarkan pengujian pada tabel

4 maka dapat disimpulkan sebagai berikut:

a. Pengaruh kontribusi peserta terhadap surplus underwriting

Nilai signifikansi dari kontribusi peserta yaitu sebesar 0,0056. Nilai tersebut lebih kecil dari 0,05 sehingga $\mathrm{H}_{0}$ ditolak dan $\mathrm{H}_{\mathrm{a}}$ diterima. Sehingga dapat disimpulkan bahwa kontribusi peserta secara parsial berpengaruh signifikan terhadap surplus underwriting asuransi umum syariah.

b. Pengaruh klaim terhadap surplus underwriting

Nilai signifikansi dari klaim yaitu sebesar 0,0234 . Nilai tersebut lebih kecil dari 0,05 sehingga $\mathrm{H}_{0}$ ditolak dan $\mathrm{Ha}_{\mathrm{a}}$ diterima. Sehingga dapat disimpulkan bahwa klaim secara parsial berpengaruh signifikan terhadap surplus underwriting asuransi umum syariah. c. Pengaruh hasil investasi terhadap surplus underwriting

Nilai signifikansi dari hasil investasi yaitu sebesar 0,2064. Sehingga $\mathrm{H}_{0}$ diterima dan $\mathrm{H}_{a}$ ditolak. Sehingga dapat disimpulkan bahwa hasil investasi secara parsial berpengaruh tidak signifikan terhadap surplus underwriting asuransi umum syariah.

Tabel 4.

Output Eviews 7 Hasil Uji $†$

\begin{tabular}{|l|l|l|}
\hline \multicolumn{1}{|c|}{ Variable } & \multicolumn{1}{c|}{ t-Statistic } & \multicolumn{1}{c|}{ Prob. } \\
\hline Kontribusi & 2,954714 & 0,0056 \\
\hline Klaim & $-2,370953$ & 0,0234 \\
\hline Hasil Investasi & $-1,287382$ & 0,2064 \\
\hline
\end{tabular}

Sumber: Data Diolah, lihat lampiran 2.

Berdasarkan tabel 2, hasil estimasi model FEM yang terbentuk adalah:

$$
\begin{aligned}
Y_{i t}=\beta_{1}+ & \beta_{2} X_{2 i t}+\beta_{3} X_{3 i t}+\beta_{4} X_{4 i t}+U_{i t} \\
S U= & 2.200 .000 .000+0,155330(\mathrm{KP})- \\
& 0,235807(\mathrm{~K})-1,654267(\mathrm{HI}) \ldots \ldots .(4.1)
\end{aligned}
$$

Interpretasi dari persamaan 4.2 sebagai berikut:

a. Nilai konstanta sebesar 2.200.000.000. Apabila variabel kontribusi peserta, klaim, dan hasil investasi dianggap konstan, maka nilai $Y$ atau surplus underwriting sebesar 2.200.000.000

b. Koefisien kontribusi peserta sebesar 0,155330 memiliki arti bahwa setiap kenaikan sebesar satu satuan dari kontribusi peserta akan meningkatkan surplus underwriting sebesar 0,155330.

c. Koefisien klaim sebesar $-0,235807$ memiliki arti bahwa setiap kenaikan sebesar satu satuan dari klaim akan 
Febrinda Eka Damayanti, et al/Jurnal Ekonomi Syariah Teori dan Terapan Vol. 3 No. 12 Desember 2016: 989-1005; ANALISIS FAKTOR-FAKTOR YANG MEMPENGARUHI SURPLUS UNDERWRITING ASURANSI UMUM SYARIAH DI INDONESIA

menurunkan surplus underwriting sebesar $-0,235807$.

d. Koefisien hasil investasi sebesar 1,654267 memiliki arti bahwa setiap kenaikan sebesar satu satuan dari hasil investasi akan menurunkan surplus underwriting sebesar -1,654267.

\section{Koefisien Determinasi}

Berdasarkan tabel 6 diperoleh nilai koefisien determinasi $\left(R^{2}\right)$ sebesar 0,217852 atau 21,7852\%. Angka tersebut menunjukkan bahwa variabel surplus underwriting dapat dijelaskan oleh variabel kontribusi peserta, klaim, dan hasil investasi sebesar 21,7852\%. Sedangkan sisanya yaitu $78,2148 \%$ dipengaruhi oleh variabel lain yang tidak termasuk dalam penelitian ini.

Tabel 5.

Output Eviews 7 Hasil Koefisien Determinasi

\begin{tabular}{|c|c|}
\hline R-Squared & Adjusted R-Squared \\
\hline 0,217852 & 0,150810 \\
\hline
\end{tabular}

Sumber: Data Diolah, lihat lampiran 2.

\section{Pembahasan}

Pengaruh Kontribusi Peserta secara Parsial terhadap Surplus Underwriting Asuransi

\section{Umum Syariah di Indonesia}

Pengaruh kontribusi peserta secara parsial terhadap surplus underwriting asuransi umum syariah dapat dilihat dari hasil uji hipotesis $t$ yang menyatakan bahwa kontribusi peserta berpengaruh positif terhadap surplus underwriting asuransi umum syariah di Indonesia periode 2012-2014.
Pengaruh positif dan signifikan menunjukkan hubungan searah antara kontribusi peserta dengan surplus underwriting. Ketika kontribusi peserta meningkat maka surplus underwriting juga mengalami peningkatan.

Hal tersebut juga didukung oleh penelitian dari Fadlullah (2014) yang menjelaskan bahwa pendapatan premi berpengaruh secara signifikan positif terhadap cadangan dana tabarru'. Premi dikenal juga dengan istilah kontribusi, dimana pendapat premi tidak lain merupakan pendapatan kontribusi yang diberasal peserta asuransi (Sula, 2004;311) sedangkan cadangan tabarru' merupakan cadangan yang dibentuk dari surplus underwriting yang tidak dibagikan kepada peserta dan kepada entitas asuransi syariah (PSAK 108).

Dana kontribusi tersebut yang telah diletakkan dalam dana tabarru' merupakan dana milik peserta asuransi dan perusahaan bertanggung jawab dalam proses pegelolaannya. Hal ini sesuai dengan ketentuan Allah dalam Q.S. An-Nisaa ayat 58:

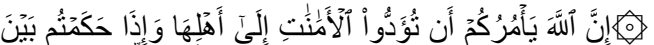

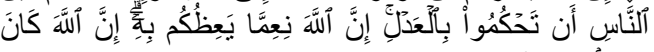

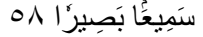
'inna llāha ya 'murukum 'an tu'addū l'amānāti 'ilā 'ahlihā wa-'idhā hakamtum bayna n-nāsi an tahkumū bi-l- 'adli 'inna llāha ni immā ya iżukum bihì 'inna llāha kāna samī 'an bașiran Artinya : "Sesungguhnya Allah menyuruh kamu menyampaikan amanat kepada yang berhak menerimanya, dan (menyuruh kamu) apabila menetapkan hukum di antara manusia supaya kamu menetapkan dengan adil. 
Sesungguhnya Allah memberi pengajaran yang sebaik-baiknya kepadamu. Sesungguhnya Allah adalah Maha Mendengar lagi Maha Melihat" (Departemen Agama Rl, 2005:168)

Dalam ayat tersebut dijelaskan bahwa amanat yang diterima harus dapat disampaikan dengan baik dan adil. Begitu pula dengan perusahaan asuransi umum syariah selaku pihak pengelola dana. Dalam proses operasionalnya perusahaan asuransi syariah harus berpegang teguh pada prinsip keadilan, kejujuran, konsisten, dan transparansi. Hal tersebut bisa dipraktekkan dalam proses pengelolaan dana kontribusi peserta, dana kontribusi merupakan amanah yang dititipkan oleh peserta asuransi, dimana perusahaan bertanggung jawab untuk mengelola sesuai dengan prinsip syariah. (Sula, 2004:315)

\section{Pengaruh Klaim secara Parsial terhadap}

\section{Surplus Underwriting Asuransi Umum}

\section{Syariah di Indonesia}

Pengaruh klaim secara parsial terhadap surplus underwriting asuransi umum syariah dapat dilihat dari hasil uji hipotesis † yang menyatakan bahwa klaim berpengaruh negatif terhadap surplus underwriting asuransi umum syariah di Indonesia periode 2012-2014.

Pengaruh negatif menunjukkan hubungan yang berbanding terbalik antara klaim dengan surplus underwriting. Sula (2004:315) menjelaskan bahwa sumber pembayaran klaim diperoleh dari rekening tabarru'. Hal tersebut menjelaskan bahwa klaim merupakan pengurang dari dana tabarru'. Sedangkan surplus underwriting terjadi ketika dana tabarru' nilainya lebih besar daripada beban asuransi yang harus ditanggung.

Hasil uji ini didukung dengan penelitian Karwati (2011), dalam penelitian ini menjelaskan bahwa yang paling mempengaruhi dalam peningkatan surplus defisit underwriting dana tabarru' adalah penurunan beban underwriting. dimana beban underwriting tersebut merupakan beban klaim yang harus dibayarkan oleh perusahaan asuransi umum syariah ketika terjadi kerugian pada peserta asuransi. Sehingga dapat disimpulkan bahwa klaim berpengaruh secara signifikan terhadap surplus underwriting asuransi umum syariah di Indonesia.

Klaim merupakan proses yang mana peserta dapat memperoleh hakhaknya berdasarkan perjanjian. Dalam proses penyelesaiannya, proses penggantian kerugian mengacu pada kondisi dan kesepakatan yang tertulis dalam polis. Yaitu, pemilihan cara penggantian yang ada pada penanggung apakah akan mengganti dengan uang tunai, memperbaiki, atau membangun ulang objek yang mengalami kerusakan. Dalam hal pembayaran klaim pihak perusahaan asuransi harus bersikap adil, sesuai dengan apa yang telah diperjanjikan pada akad. hal tersebut sesuai dengan Q.S Al-anfaal 27 
Febrinda Eka Damayanti, et al/Jurnal Ekonomi Syariah Teori dan Terapan Vol. 3 No. 12 Desember 2016: 989-1005; ANALISIS FAKTOR-FAKTOR YANG MEMPENGARUHI SURPLUS UNDERWRITING ASURANSI UMUM SYARIAH DI INDONESIA

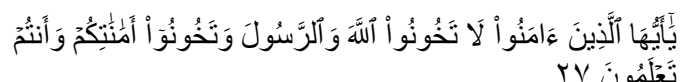

yā-'ayyuhā lladhīna 'āmanū lā takhūnū llāha wa-r-rasūla wa-takhūnū 'amānātikum wa-'antum ta 'lamūna

Artinya: "Hai orang-orang yang beriman, janganlah kamu mengkhianati Allah dan Rasul (Muhammad) dan (juga) janganlah kamu mengkhianati amanat-amanat yang dipercayakan kepadamu, sedang kamu mengetahui" (Departemen Agama Rl, 2005:350)

Ayat tersebut menjelaskan bahwa

perusahaan asuransi selaku lembaga kevangan syariah harus dikelola sesuai dengan prinsip syariah. Perusahaan asuransi harus dapat memegang amanah yang telah dipercayakan oleh peserta asuransi dengan baik. Hal tersebut dapat dipraktekkan dalam proses klaim, dimana perusahaan selaku pihak pengelola harus bersikap jujur serta adil dalam proses penyelesaian klaim. Perusahaan asuransi tidak diperbolehkan untuk memperlambat penyelesaian klaim, karena klaim adalah suatu resiko yang telah diantisipasi sejak awal oleh perusahaan asuransi. Selain itu, klaim merupakan hak peserta, dan dananya diambil dari dana tabarru' semua peserta. Karena itu, wajib bagi pengelola untuk melakukan proses klaim secara cepat, tepat dan efisien. Itu merupakan bagian dari amanat yang harus dijalankan oleh pengelola sebagaimana yang telah diperjanjiakan (Sula, 2004:260)

Pengaruh Hasil Investasi secara Parsial terhadap Surplus Underwriting Asuransi Umum Syariah di Indonesia
Pengaruh hasil investasi secara parsial terhadap surplus underwriting asuransi umum syariah dapat dilihat dari hasil uji hipotesis $t$ yang menyatakan bahwa hasil investasi berpengaruh negatif terhadap surplus underwriting asuransi umum syariah di Indonesia periode 20122014. Hasil pengujian ini tidak sesuai dengan hipotesis pertama yang menyatakan bahwa hasil investasi secara signifikan berpengaruh terdahap surplus underwriting.

Hasil dari investasi pada cadangan dana tabarru' digunakan oleh pengelola untuk pembayaran beban asuransi (klaim dan premi reasuransi) dan pada akhir periode ketika terdapat selisih antara kontribusi dan beban asuransi, maka akan diperoleh surplus underwriting (Soemitra, 2009:281).

Samuelson dan Nordhaus (1993:183) menjelaskan faktor-faktor yang mempengaruhi nilai hasil investasi. Pertama adalah pengaruh nilai tukar dimana dalam jangka pendek, penurunan tingkat nilai tukar akan mengurangi investasi melalui pengaruh negatifnya pada absorbs domestic. Karena penurunan tingkat kurs ini akan menyebabkan nilai riil aset masyarakat yang disebabkan kenaikan tingkat hargaharga secara umum dan selanjutnya akan menurunkan permintaan domestik masyarakat. Gejala diatas pada tingkat perusahaan akan direspon dengan penurunan pada pengeluaran/alokasi modal pada investasi. Kedua adalah 
pengaruh tingkat suku bunga dimana tingkat bunga mempunyai pengaruh yang signifikan pada dorongan untuk berinvestasi. Pada kegiatan produksi, pegelolaan barang-barang modal atau bahan baku produksi memerlukan modal (input) lain untuk menghasilkan output/barang final. Ketiga adalah pengaruh tingkat inflasi dimana tingkat inflasi berpengaruh pada tingkat investasi. Hal ini disebabkan karena tingkat inflasi yang tinggi akan meningkatkan resiko proyek-proyek investasi dan dalam jangka panjang inflasi yang tinggi dapat mengurangi rata-rata masa jatuh pinjam modal serta menimbulkan distorsi tentang harga-harga relatif.

Hasil penelitian yang menunjukkan bahwa hasil investasi berpengaruh negatif terhadap surplus underwriting sesuai dengan penelitian yang dilakukan oleh Satata (2015), dari hasil penelitian diketahui bahwa hasil investasi berpengaruh negatif terhadap laba asuransi. Laba asuransi pada asuransi syarah untuk asuransi kerugian diperoleh dari surplus underwriting yang sebelumnya telah dilakukan pembagian bagi hasil antara perusahaan dengan peserta sebagaimana yang telah diperjanjikan atau menjadi akad di awal ketika baru masuk asuransi syariah (Sula, 2004:319).

Tujuan utama dari kebijakan investasi adalah untuk implementasi rencana program yang dibuat agar dapat mencapai return positif, dengan stabilitas yang tinggi dari aset yang tersedia untuk diinvestasikan (Soemitra, 2009:283). Allah berfirman dalam Q.S alLuqman 34:

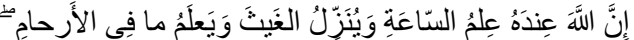

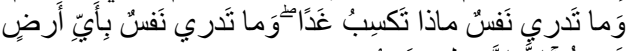

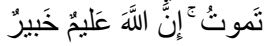

'inna llāha indahū ilmu s-sāati wayunazzilu I-ghaytha wa-ya lamu mā $f i$ l- 'arhāmi wa-mā tadrī nafsun mādhā taksibu ghadan wa-mā tadrī nafsun bi-'ayyi 'arḍin tamūtu inna llāha alimun khabìrun

Artinya: "Sesungguhnya Allah, hanya pada sisi-Nya sajalah pengetahuan tentang Hari Kiamat; dan Dia-lah Yang menurunkan hujan, dan mengetahui apa yang ada dalam rahim. Dan tiada seorang pun yang dapat mengetahui (dengan pasti) apa yang akan diusahakannya besok. Dan tiada seorang pun yang dapat mengetahui di bumi mana dia akan mati. Sesungguhnya Allah Maha Mengetahui lagi Maha Mengenal" (Departemen Agama Rl, 2005:)

Ayat tersebut menjelaskan bahwa tidak seorangpun yang mengetahui apa yang akan diperbuat dan diusahakannya, serta apa yang akan terjadi pada hari esok. Jika dihubungkan dengan asuransi umum syariah, masalah ketidakpastian sesuai dengan proses pengelolaan dana tabarru' yang diinvestasikan. Perusahaan asuransi syariah hanya bisa merencanakan suatu kegiatan investasi, namun tidak dapat dapat memastikan hasil yang akan didapatkan dari kegiatan investasi tersebut sebab hasil akhir dari usaha merupakan suatu sunatullah.

Pengaruh Kontribusi Peserta, Klaim, dan Hasil Investasi secara Simultan terhadap Surplus Underwriting Asuransi Umum Syariah di Indonesia.

Variabel kontribusi peserta, klaim, dan hasil investasi memiliki nilai F-hitung 
Febrinda Eka Damayanti, et al/Jurnal Ekonomi Syariah Teori dan Terapan Vol. 3 No. 12 Desember 2016: 989-1005; ANALISIS FAKTOR-FAKTOR YANG MEMPENGARUHI SURPLUS UNDERWRITING ASURANSI UMUM SYARIAH DI INDONESIA

sebesar 3,249512 dengan nilai signifikansi sebesar 0,0332. Dimana nilai signifikansi lebih besar dari 0,05 Maka dapat dinyatakan bahwa $\mathrm{H}_{0}$ diterima karena nilai Hasil uji F menunjukkan bahwa variabel kontribusi peserta, klaim, dan hasil investasi berpengaruh tidak signifikan terhadap surplus underwriting asuransi umum syariah di Indonesia secara simultan.

Berdasarkan hasil uji koefisien determinasi berganda dapat diketahui nilai R-square nya sebesar 0,217852. Artinya sebesar 21,7852\% perubahan surplus underwriting dapat dijelaskan oleh variabel kontribusi peserta, klaim, dan hasil investasi sedangkan sisanya sebesar $78,2148 \%$ dijelaskan oleh variabel lain diluar ketiga variabel bebas yang digunakan dalam penelitian ini.

Hasil penelitian ini sesuai dengan hasil penelitian yang dilakukan oleh Satata (2015) yang menyimpulkan bahwa premi dan hasil investasi serta surplus underwrting dana tabarru' berpengaruh signifikan terhadap laba asuransi umum syariah. Laba asuransi pada asuransi syarah untuk asuransi kerugian diperoleh dari surplus underwriting yang sebelumnya telah dilakukan pembagian bagi hasil antara perusahaan dengan peserta sebagaimana yang telah diperjanjikan atau menjadi akad di awal ketika baru masuk asuransi syariah (Sula, 2004:319)

Surplus underwriting merupakan selisih lebih total kontribusi peserta ke dalam dana tabarru' ditambah kenaikan aset reasuransi setelah dikurangi pembayaran santunan/klaim, kontribusi reasuransi dan kenaikan cadangan teknis, dalam satu periode (Peraturan OJK). Ketika terjadi surplus underwriting, perusahaan asuransi dapat membagikan keuntungan tersebut kepada peserta dan perusahaan asuransi selaku pengelola yang pembagiannya harus disetujui terlebih dahulu oleh peserta dan dituangkan dalam akad (Fatwa DSN-MUI). Pada dasarnya keuntungan menurut islam merupakan suatu sunatullah, manusia tidak bisa memastikan apa yang akan terjadi, yang dapat dilakukan adalah berusaha sesuai dengan kemampuan yang dimiliki. Hal tersebut seperti yang tersirat dalam Q.S An-Nisaa ayat 32 berikut ini:

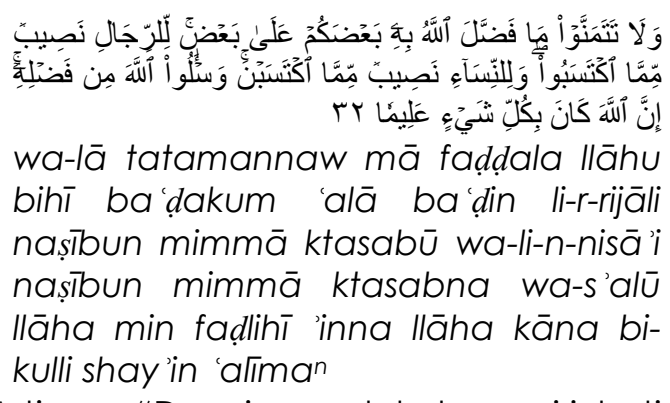
Artinya: "Dan janganlah kamu iri hati terhadap apa yang dikaruniakan Allah kepada sebahagian kamu lebih banyak dari sebahagian yang lain. (Karena) bagi orang laki-laki ada bahagian dari pada apa yang mereka usahakan, dan bagi para wanita (pun) ada bahagian dari apa yang mereka usahakan, dan mohonlah kepada Allah sebagian dari karunia-Nya. Sesungguhnya Allah Maha Mengetahui segala sesuatu"

Ayat tersebut jika dihubungkan dengan penelitian ini, bahwasanya segala sesuatu yang terjadi merupakan kehendak Allah SWT, termasuk Surplus underwriting yang terjadi pada asuransi 
Febrinda Eka Damayanti, et al/Jurnal Ekonomi Syariah Teori dan Terapan Vol. 3 No. 12 Desember 2016: 989-1005; ANALISIS FAKTOR-FAKTOR YANG MEMPENGARUHI SURPLUS UNDERWRITING ASURANSI UMUM SYARIAH DI INDONESIA

umum syariah. Karena hanya Allah yang memiliki kuasa untuk memberikan rezeki, dan setiap usaha pasti mendapat balasan atas apa yang telah mereka usahakan. Jadi, meskipun variabel konrtibusi peserta, klaim dan hasil investasi memiliki pengaruh yang signifikan terhadap surplus underwriting, tidak dapat dipungkiri juga bahwa terdapat kemungkinan variabel tersebut tidak menyebabkan perubahan pada surplus underwriting.

\section{SIMPULAN}

Berdasarkan hasil analisis dan pembahasan yang telah dijelaskan di bab terdahulu, maka simpulan dari penelitian ini adalah

1. Kontribusi peserta, klaim, dan hasil investasi secara bersama-sama atau simultan berpengaruh signifikan terhadap surplus underwriting asuransi umum syariah di Indonesia pada signifikansi a $5 \%$ dengan persamaan $Y=2.200 .000 .000+0,155330(\mathrm{KP})-$ $0,235807(\mathrm{~K})-1,654267(\mathrm{HI})$

2. Kontribusi peserta secara parsial berpengaruh positif dan signifikan, variabel klaim berpengaruh negatif dan signifikan, sedangkan variabel hasil investasi tidak berpengaruh signifikan terhadap surplus underwriting asuransi umum syariah di Indonesia pada signifikansi a $5 \%$.

\section{DAFTAR PUSTAKA}

Aijja, Shochrul R dkk. 2011. Cara Cerdas Menguasai Eviews. Jakarta. Salemba Empat

Dewi, Gemala. 2004. Aspek-Aspek Hukum dalam Perbankan dan Perasuransian
Syariah di Indonesia. Jakarta: Kencana Prenada Media Group

Fadlullah, Arif. 2014. Pengaruh Pendapatandan Hasil Investasi terhadap Cadangan Dana Tabarru'. Skripsi tidak diterbitkan. Jakarta UIN Syarif Hidayatullah

Fatwa Dewan Syari'ah Nasional NO: 21/DSN-MUI/X/2001Tentang Pedoman Umum Asuransi Syari'ah

Ghofar, Abd. 2012. Pengaruh Premi, Klaim, Investasi dan Profitabilitas Terhadap Pertumbuhan Aset Pada Perusahaan Asuransi Syariah Di Indonesia. Skripsi tidak diterbitkan. Yogyakarta UIN SUnan Kalijaga.

Greene, William H. 1991. Econometric Analysis. New York: Macmillan Publishing Company.

Gujarati, Damodar N dan Dawn C. Porter. 2013. Dasar-Dasar Ekonometrika. Edisi 5 Buku 2. Jakarta: Salemba Empat.

Huda, Nurul dan Mustafa. 2009. Current Issues Lembaga Keuangan Syariah. Jakarta: Kencana Prenada Media Group

Huda, Nurul. 2010. Lembaga Keuangan Islam: Tinjauan Teoritis dan Praktik. Jakarta: Kencana Predana Media Group

Humaidi. 2010. Mekanisme PendistribusianSurplus Underwriting kepada Peserta Asuransi Kebakaran IStudi pada PT. Asuransi Umum Bumiputeramuda 1967 Unit Syariah. Skripsi tidak diterbitkan. Jakarta Uin Syarif Hidayatullah

Indrianto dan Supomo. 1999. Metodologi Penelitian Bisnis untuk Akuntansi dan Manajemen. Edisi Pertama. Yogyakarta: BPFE Yogyakarta

Karwati. Euis Lia. 2011. Metode alokasi surplus underwriting dana tabarru pada asuransi kerugian syariah. Skripsi tidak diterbitkan. Jakarta Uin Syarif Hidayatullah Jakarta.

Otoritas Jasa Keuangan, 2015. Ikhtisar Data Kevangan IKNB Syariah, (online), (www.ojk.go.id, diakses 22 Oktober 2015)

Puspitasari, Novi. 2012. Model Proporsi Tabarru' dan Ujrah pada Bisnis Asuransi Umum Syariah di Indonesia. Jurnal Akuntansi dan Keuangan Indonesia Volume 9-No 1. Juni 2012 
Rahman, Muh. Fudhail. 2011. Asuransi dalam Persoejtif Hukum Islam. AL'ADALAH Vol X, No. 1 JAnuari 2011

Samuelson, Paul A dan Nordhus William. 1993. Mikro Ekonomi. Edisi Ke-14. Jakarta: Erlangga

Satata, Elsha Dwi Angganis. 2015. Pengaruh Premi dan Hasil Investasi serta Surplus Underwriting Dana Tabarru' terhadap Laba Asuransi PT Asuransi Jasindo Takaful. Skripsi tidak diterbitkan. Surabaya: Universitas Airlangga

Soemitra, Andri. 2009. Bank dan Lembga Kevangan Syariah. Jakarta: Kencana Pranada Media Group

Sudarsono, Heri. 2003. Bank dan lembaga keuangan syari'ah. Yogyakarta: EKONISIA)

Sula, Muhammad Syakir. 2004. Asuransi Syariah (Life and General); konsep dan sistem operasional. Jakarta: Gema Insani 